\title{
The Effect of Roselle (Hibiscus sabdariffa) Extract on Malondialdehyde Level in Rat Liver
}

\author{
Fadhilah Sharfina Alyani ${ }^{1}$, Retno Yulianti ${ }^{*}$, Maria Selvester Thadeus ${ }^{1}$ \\ ${ }^{1}$ Faculty of Medicine, University of Pembangunan Nasional "Veteran" Jakarta, \\ South Jakarta 12450, Indonesia
}

\begin{abstract}
This study aimed to determine the efficacy of roselle flower extract in reducing the Malondialdehyde (MDA) level in rats after induction of $20 \%$ ethanol. This experimental study used a post-test design on 24 male white rats, Wistar strain which were grouped into six type of treatment. The K1 group was given daily aquadest only, K2 was given $20 \%$ ethanol. K3 was given $20 \%$ ethanol and vitamin C, K4 was given $20 \%$ ethanol and $250 \mathrm{mg} / \mathrm{kgBW} /$ day roselle flower extracts, $\mathrm{K} 5$ was given $20 \%$ ethanol and $500 \mathrm{mg} / \mathrm{kgBW} /$ day roselle flower extract, $\mathrm{K} 6$ was given $20 \%$ ethanol and $750 \mathrm{mg} / \mathrm{kgBW} /$ day roselle flower extract. Each group received treatment for 30 days. At the time of termination, the rat's liver was collected and the liver's MDA level was examined. One Way Anova test and the Post Hoc Tukey test were used for data analysis. There was a decrease in MDA levels $(3.1578 \pm 0.37 \mathrm{ng} / \mathrm{ml})$ in K4 compared to $\mathrm{K} 2$ as well as to $\mathrm{K} 5$ and $\mathrm{K} 6$ with higher extract concentrations. Thus, despite its benefit as antioxidant, excess of flavonoid compounds undergoing oxidation will produce a metabolite compound that can damage the endogenous antioxidant. Hence, $250 \mathrm{mg} / \mathrm{kgBW} /$ day roselle flower extract given daily can reduce MDA levels in mice induced with $20 \%$ alcohol.
\end{abstract}

Keywords: antioxidant, ethanol, malondialdehyde, roselle

\section{INTRODUCTION}

Alcoholic beverages have become inseparable part of human civilization. Many traditional drinks in Indonesia such as tuak, sopi, arak, and badeg are consumed by local communities as part of their local tradition (Riskiyani et al. 2015). According to Riskesdas (MoH RI 2018), 4.6\% of the population consumed alcoholic drinks and the highest prevalence was found in East Nusa Tenggara (NTT) province, which is $17.7 \%$.

The type of alcoholic drinks accessed were traditional alcoholic drinks (38.7\%), beer with $(29.5 \%)$, wine $(21.6 \%)$ and whiskey $(3.8 \%)$ respectively. In Indonesia, there are many types of alcohol with various ethanol levels. According to Presidential Regulation of the Republic of Indonesia no 74 year 2013, alcohol beverages are divided based on the ethanol levels: Group A with 1\%-5\% ethanol level, group B with 5\%$20 \%$ ethanol level, and group C with $20 \%-55 \%$ ethanol level.

Excessive alcohol consumption can cause various health problems both in the short and long term. These include central nervous system disorders, cardiovascular disorders and digestive disorders as well as psychological disorders that can cause changes and distortions of an individual's behavior and minds so that it can endanger the individual and others (Tritama 2015).

In metabolism process, alcohol is converted to acetaldehyde. The acetaldehyde formed is oxidized in the liver. Alcohol metabolism in the liver cells (hepatocytes) cause an increase of free radicals that react with poly unsaturated fatty acids leading to lipid peroxidation which produce Malondialdehyde (MDA). This triggers oxidative stress in the liver tissue (Zakhari 2006; Ayala et al. 2014)

Oxidative stress in the body caused by free radicals due to Lipid peroxidation reactions can be neutralized by endogenous or exogenous antioxidants. Many Indonesian natural ingredients contain antioxidants with various types of active ingredients and can be obtained at affordable prices (Werdhasari 2014). One of such plants is roselle (Hibiscus sabdariffa L.).

\footnotetext{
"Corresponding Author: tel: +6287884946602, email: retnoyulianti@upnvj.ac.id
} 
roselle cultivation can be found in the low and highlands. According to research by Hidayah (2011) the highest antioxidant activity came from the roselle found in the lowlands.

Roselle petals is often used in food processing, it contains anthocyanin which gives color to the roselle petals and is believed to have antioxidant activity that can neutralize free radicals (Nurnasari \& Khuluq 2017). Anthocyanins belong to flavonoids group which can act as antioxidant. The conjugated double bond system in anthocyanin helps in capturing free radicals (Ulilalbab et al. 2015). In addtion to anthocyanins, roselle petals also contain betacarotene, vitamin $\mathrm{C}$, thiamine, riboflavin, niacin and flavonoids (Mardiah et al. 2009).

Ulialbab et al. (2015) reported that roselle extract has the ability to reduce levels of malondialdehyde. Dianasari and Fajrin (2015) was using roselle extracts of $250 \mathrm{mg} / \mathrm{kgBW} /$ day, $500 \mathrm{mg} / \mathrm{kgBW} /$ day, and $750 \mathrm{mg} / \mathrm{kgBW} /$ day doses in diabetic mice, the results obtained at doses of $500 \mathrm{mg} / \mathrm{kgBW} /$ day and $750 \mathrm{mg} / \mathrm{kgBW} /$ day had antidiabetic activity. Further, Zuraida et al. (2015) reported that roselle extract can reduce MDA levels and increases catalase enzyme levels in rats exposed to Carbon Tetrachloride, and Pramita (2014) reported that roselle extract can reduce MDA levels in rat eyes and can increase SOD levels in rat eyes that have been exposed to $300 \mathrm{rad}$ gamma radiation. Therefore, the researchers were interested in investigating the efficacy of roselle extract at doses of $250 \mathrm{mg} /$ $\mathrm{kgBW} /$ day, $500 \mathrm{mg} / \mathrm{kgBW} /$ day, and $750 \mathrm{mg} /$ $\mathrm{kgBW} /$ day levels on malondialdehyde level in ethanol induced rats' liver.

\section{METHODS}

\section{Design, location, and time}

The research was held in Pharmacology Laboratorium Medicine Faculty of Padjajaran University from July to December 2019. The study was conducted based on ethical treatment agreement from Ethics Comission, UPN Veteran Jakarta. This experimental study used a post test-only control group design. The study was conducted at the Pharmacology Laboratorium with treatments to one or more experimental groups. The results were then compared with the control group.

\section{Material and tools}

The subjects of this study were 24 male white rats (Rattus norvegicus) Wistar strain obtained from the Pharmacology and Therapy Laboratory of the Faculty of Medicine, Padjajaran University, Bandung. The mice were aged 2-3 month old with a body weight of 250-300 grams. Mice which were ill before treatment and had any anatomic abnormalities were excluded from the study.

The tools used in this study were: spectrophotometer, centrifugator, micropipette, $1.5 \mathrm{ml}$ and $2 \mathrm{ml}$ microtube, filter paper, and sample tubes.The material used in this study were roselle flower extract (Hibiscus sabdariffa L.), ethanol $20 \%$ solution which were fed to the rats everyday for 30 days. The type of extraction used was multilevel maceration with water solvents. The extract dosage used were $250 \mathrm{mg} /$ $\mathrm{kgBW} /$ day, $500 \mathrm{mg} / \mathrm{kgBW} /$ day, $750 \mathrm{mg} / \mathrm{kgBW} /$ day. The doses was chosen according to Zuraida et al. (2015) where the study found that $250 \mathrm{mg} /$ $\mathrm{kgBW}$ and $500 \mathrm{mg} / \mathrm{kgBW}$ of roselle extract were able to reduce MDA level in rats' blood induced with carbon tetracloride. Meanwhile the dose of $750 \mathrm{mg} / \mathrm{kBW}$ in this research used to determine the lethal dose. Moreover, other antioxidant used in this study were vitamin C at a dose of $1.8 \mathrm{mg} /$ day (Christijanti et al. 2011).

\section{Procedures \\ Extraction}

Roselle flower extract was made from dried roselle petals. Twenty five grams of roselle petals macerated with water in $250 \mathrm{ml}$ Erlenmeyer and covered with aluminum foil. Then, stored in the refrigerator for at least 24 hours. After 24 hours, it was filtered (Oktiarni et al. 2016). Examination of the characteristics of the extract identified the chemical content of the roselle flower extract included alkaloids, saponins, phenolics, flavonoids, triterpenoids, and glycosides.

\section{Intervention}

The treatment was divided into six groups, four rats were assigned per group: in the negative control group/ normal (K1) rats were given standard feed and aquades; in the positive control group I (K2) rats were given standard feed and $20 \%$ ethanol as much as $2 \mathrm{ml} /$ day; in the positive control group II (K3) rats were given standard feed, $20 \%$ ethanol as much 
as $2 \mathrm{ml} /$ day, and vitamin $\mathrm{C}$ dose $1.8 \mathrm{mg} /$ day; in the treatment group rats given $20 \%$ and roselle flower extract with differenet dosages namely in $\mathrm{K} 4$ rats were given roselle flower extract 250 $\mathrm{mg} / \mathrm{kgBW} /$ day, in $\mathrm{K} 5$ rats were given roselle flower extract $500 \mathrm{mg} / \mathrm{kgBW} / \mathrm{day}$, and in $\mathrm{K} 6$ rats were given roselle flower extract $750 \mathrm{mg} /$ $\mathrm{kgBW} /$ day. In groups $\mathrm{K} 2, \mathrm{~K} 3, \mathrm{~K} 4, \mathrm{~K} 5$, and $\mathrm{K} 6$ rats were given ethanol $20 \%$ every day for 30 days. Each the roselle extract and vitamin $\mathrm{C}$ was given one hour after the administration of ethanol $20 \%$ orally. The rats were terminated on the last day after the 30 days of intervention. The mice were anesthetized before being terminated. The anesthetic substance used was ketamine injected intraperitoneally with a dosage of $75-100 \mathrm{mg} /$ $\mathrm{kgBW}$. The administration of ketamine was done in an early stage of euthanasia process because it causes quick unconsciousness about three to five seconds after injection (AVMA 2013).

\section{Measurement of malondialdehyde}

The liver were weighed as much as 10 $\mathrm{mg}$ then crushed until smooth and put in the appendorf tube; $100 \mathrm{cc}$ distilled water was then added. Homogenate was added $100 \mu \mathrm{l}$ of $100 \%$ Trichloroacetic Acid (TCA) solution, thiobarbiturate $\mathrm{Na} 1 \%$, and $\mathrm{HCl} 1 \mathrm{~N} 250 \mu$ l. The mixture was centrifuged until homogeneous and incubated for 20 minutes at $100^{\circ} \mathrm{C}$. After that, centrifuged at $3500 \mathrm{rpm}$ for 10 minutes. The results were read on a spectrophotometer with a wavelength of $532 \mathrm{~nm}$. The results of the spectrophotometer were converted into MDA standard curves (Fitria et al. 2015).

The standard curve was made to find out the relationship between the concentration of the solution and the absorbance value so that the concentration of the sample can be measured. Tetreaethoxypropane (TEP) solution was used to create the MDA standard curve. MDA standard curves were made by reacting TEP in various concentrations with $0.67 \%$ thio-barbituric acid (TBA). The standard Tetraethoxypropane (TEP) solution used was $10.0 ; 20.0 ; 40.0 ; 60.0 ; 80.0$; 100.0 and $120.0 \mu \mathrm{l}$; distilled water was added until each volume reached $250 \mu 1$. After that, 1.25 $\mathrm{ml}$ of Trichloroacetic acid (TCA) $20 \%$ and $0.5 \mathrm{ml}$ of Thiobarbituric Acid (TBA) $0.67 \%$ were added and solution was shaken until homogeneous. All samples were heated for 30 minutes at $100^{\circ} \mathrm{C}$ and cooled immediately (Agustini 2017).

\section{Phytochemical tests}

Phytochemical tests was done to determine the content of the active composition in roselle petals extract. Roselle extract was dissolved in each special solvent to determine the content in the extract. The tests carried out included alkaloid tests, flavonoid tests, tests saponin, tannin test, and triterpenoid test. For alkaloid test, the steps included roselle extract of $0.1 \mathrm{~g}$ reacted with 10 $\mathrm{ml}$ of chloroform and a few drops of ammonia. The chloroform fraction wass separated and acidified with a few drops of concentrated $\mathrm{H}_{2} \mathrm{SO}_{4}$ and divided into 3 test tubes, then Dragendorf reagents, Meyer reagents, and Wagner reagents were added.

In the flavonoid test, roselle extract was added with $0.1 \mathrm{mg}$ and 0.4 magnesium tablets $\mathrm{ml}$ of amyl alcohol (a mixture of 37\% hydrochloric acid and $95 \%$ ethanol by volume) and $4 \mathrm{ml}$ of alcohol then the mixture was shaken. The steps for saponin test detected by foam testing in hot water. Extract was heated and then the foam was taken. Stable foam during 10 minutes and did not disappear with the addition of 1 drop of $\mathrm{HCl} 2 \%$. The steps of tanin test, extract as much as $1 \mathrm{~g}$ added with $10 \mathrm{ml}$ of distilled water and then bring to a boil. After cooling the filtrate was added with $\mathrm{FeCl} 31 \%$. And the last step were the triterpenoid and steroid test. Extract as much as $1 \mathrm{~g}$ was dissolved with $25 \mathrm{ml}$ of hot ethanol $50^{\circ} \mathrm{C}$, then filtered into porcelain dish and dried. The residue was dissolved with ether and transferred into a test tube, then 3 drops of anhydrous acetic acid and 1 concentrated $\mathrm{H}_{2} \mathrm{SO}_{4}$ were added. Extracts with purple or red color indicated the presence triterpenoids and green or blue extracts indicated steroids (Syafitri et al. 2014).

\section{Data analysis}

Data were analyzed using the One way ANOVA test with a significance level set at 0.05 to determine whether there were differences in MDA levels in all groups. Post-Hoc test was conducted following the ANOVA test to determine the differences in each group. Data were analyzed using SPSS 21 software.

\section{RESULTS AND DISCUSSION}

\section{Phytochemical test}

The qualitative phytochemical test results of roselle flower extract revealed that the 
extract used in the study contained antioxidant compounds as shown in Table 1. The qualitative phytochemical test showed that roselle flower extract contained flavonoid, saponin, phenolic, triterpenoid, glycoside, and alkaloids and roselle flower did not contain tannin and steroid. Previous research has reported that roselle flowers contains chemical properties including anthocyanin, beta-carotene, vitamin $\mathrm{C}$, thiamine, riboflavin, flavonoids and niacin (Aisiyah et al. 2017). Anthocyanin, a flavonoid, is a natural antioxidant and is the red pigment of roselle flowers (Aisiyah et al. 2017). The long conjugated double bond system in anthocyanins is thought to capture free radicals by breaking down the propagation chain of free radicals, where all hydroxyl groups $(\mathrm{OH})$ in ring $\mathrm{B}$ can contribute or act as electron or hydrogen donors so that cleaning or interception of free radicals occurs (Priska et al. 2018). In addition to anthocyanins as antioxidants, other phytochemical compounds contained in roselle flower such as saponin, alkaloid, triterpenoids, glycoside, and phenolics also have function as antioxidants and can be used as antibacterials (Nurnasari \& Khuluq 2017). However, we did not find Tannin and Steroid in the roselle extract. The tannin content may decrease with increasing extraction time. This is because all the compounds contained, especially tannins, will be extracted and mixed with solvents (Sukardi et al. 2007). Other study also found that roselle flower petals, whether they are fresh or extracted with ethanol did not contain any steroid compounds (Hayati et al. 2012).

\section{Malondialdehyde measurement}

Data were analyzed using one way ANOVA test. The results obtained a significance value of 0.001 . This means the extract given has an effect on liver malondialdehyde level induced with $20 \%$ ethanol.

Table 2 indicates data from the average liver MDA level in each group assessed from the rats' liver tissue taken after 30 days of treatments. The differences in the mean MDA levels for each group, ranged from $2.4 \mathrm{ng} / \mathrm{ml}$ to $3.73 \mathrm{ng} / \mathrm{ml}$. Data analysis using One Way Anova showed that there was a significant difference in malondialdehyde levels between groups $(p=0.001 ; \alpha=0.05)$. The lowest average MDA level was found in K3 $(2.4334 \pm 0.17)$, the group treated with vitamin C. This is because vitamin Cacts as potent antioxidant
Table 1. Phytochemical test

\begin{tabular}{lc}
\hline \multicolumn{1}{c}{ Phytochemical Test } & Results \\
\hline Flavonoid & + \\
Saponin & + \\
Tannin & - \\
Phenolic & + \\
Triterpenoid & + \\
Steroid & - \\
Glycoside & + \\
Alkaloid & + \\
\hline
\end{tabular}

by acting as an electron donor to ward off free radicals (Lieberman \& Peet 2018). This group is the reference to determine the efficacy of roselle extract compared to a well-known or standardize antioxidant which is the vitamin $\mathrm{C}$. The average MDA level in $\mathrm{K} 4$, given roselle extract of 250 $\mathrm{mg} / \mathrm{kgBW} /$ day is $3.1578 \pm 0.37$ and it showed a statistically non-significant difference with the K3. This supports the fact that roselle extract of $250 \mathrm{mg} / \mathrm{kgBW} /$ day can work as good as vitamin C. This is in line with research by Zuraida et al. (2015) which showed that roselle extract at a dose of $250 \mathrm{mg} / \mathrm{kgBW} /$ day in rats exposed to carbon tetrachloride was able to reduce MDA levels. This might due to the combination of anthocyanin or flavonoid compounds contained in roselle flowers. The flavonoid compounds in the roselle flower are able to ward off free radicals through

Table 2. Differences of average levels of malondialdehyde

\begin{tabular}{|c|c|c|c|}
\hline Group & Treatment & $\begin{array}{c}\text { MDA } \\
\text { Level } \pm \text { SD }(\mathrm{ng} / \mathrm{ml})\end{array}$ & $\mathrm{p}^{*}$ \\
\hline K 1 & Negative control & $3.5668 \pm 0.48^{\mathrm{b}}$ & 0.001 \\
\hline K 2 & Positive control 1 & $3.6830 \pm 0.32^{\mathrm{b}}$ & \\
\hline K 3 & $\begin{array}{l}\text { Positive control } 2 \\
\text { (Vitamin C) }\end{array}$ & $2.4334 \pm 0.17^{\mathrm{a}}$ & \\
\hline K 4 & $\begin{array}{l}\text { Roselle extract } \\
250 \mathrm{mg} / \mathrm{kgBW} / \text { day }\end{array}$ & $3.1578 \pm 0.37^{\mathrm{a}}$ & \\
\hline K 5 & $\begin{array}{l}\text { Roselle extract } \\
500 \mathrm{mg} / \mathrm{kgBW} / \text { day }\end{array}$ & $3.6053 \pm 0.54^{\mathrm{b}}$ & \\
\hline K 6 & $\begin{array}{l}\text { Roselle extract } \\
750 \mathrm{mg} / \mathrm{kgBW} / \text { day }\end{array}$ & $3.7306 \pm 0.28^{\mathrm{b}}$ & \\
\hline
\end{tabular}


the process of radical scavenging by giving one hydrogen atom from the group to react with free radicals (Zuraida et al. 2015). As shown in Harun et al. (2017) that administration of tempeh which contains flavonoids to rats can reduce the level of malondialdehyde.

The highest average MDA is at $\mathrm{K} 6$ with an average of $3.7306 \pm 0.28$, which is the group treated with roselle extract at a dose of $750 \mathrm{mg} / \mathrm{kg} / \mathrm{BW}$. It also shows that the average $\mathrm{K} 5$ and $\mathrm{K} 6$ are higher than $\mathrm{K} 4$, which means that each additional dose can cause an increase from the average MDA. It means that dose of $500 \mathrm{mg} / \mathrm{kgBW} /$ day and 750 $\mathrm{mg} / \mathrm{kgBW} /$ day was less effective in neutralizing free radical. According to Lemmens et al. (2014), flavonoid compounds undergoing oxidation will produce a metabolite compound that can damage the endogenous antioxidant glutathione (GSH). The effect of the damage to endogenous antioxidants is thought to cause a decrease in intracellular antioxidant action which causes the Reactive Oxygen Species (ROS) formed to react with hepatocyte cell molecules so that the lipid peroxidation process still occurs and a high MDA is instead produced (Lemmens et al. 2014).

In addition, there is no significant difference between $\mathrm{K} 5$ and $\mathrm{K} 6$ with $\mathrm{K} 1$ and $\mathrm{K} 2$. This shows that the $\mathrm{K} 1$ and $\mathrm{K} 2$ rats were already under stress, the stress increased the formation of free radicals. The formation of Reactive Oxygen Species (ROS) or active free radicals cause excessive lipid peroxidation reactions between ROS and polyunsaturated fatty acids contained in the hepatocyte cell membrane wall. This causing damage to the structure and function of the hepatocyte cells. The final product of the lipid peroxidation process is an increase in the levels of malondialdehyde (MDA) (Ayala et al. 2014).

\section{CONCLUSION}

The qualitative phytochemical test showed that roselle flower extract contained flavonoid, saponin, phenolic, triterpenoid, glycoside, and alkaloids as anti oxidants but did not contain tannin and steroid. The administration of roselle flower extract $250 \mathrm{mg} / \mathrm{kgBW} /$ day for 30 days to the rats' liver malondialdehyde level induced by $20 \%$ ethanol was comparable to the administration of Vit C $1.8 \mathrm{mg} /$ day as the standard antioxidant. While higher dossage of roselle flower extract $500 \mathrm{mg} / \mathrm{kgBW} /$ day and $750 \mathrm{mg} / \mathrm{kgBW} /$ day did not show comparable efficacy in reducing the rats' liver MDA levels.

\section{ACKNOWLEDGEMENT}

This paper and the research reported would not be completed without the exceptional support of my lecturers and also the authors are grateful for the support from Medical Faculty, University of Pembangunan Nasional "Veteran" Jakarta.

\section{AUTHOR DISCLOSURES}

The authors have no conflict of interest.

\section{REFERENCES}

Agustini NWS 2017. Kemampuan pigmen karoten dan xantofil mikroalga Porphyridium crunetum sebagai antioksidan pada domba. Informatika Pertanian 26(1):1-12. http:// dx.doi.org/10.21082/ip.v26n1.2017.p1-12.

Aisiyah S, Harjanti R, Nopiyanti V. 2017. Pemanfaatan bunga rosella (Hibiscus sabdariffa L.) sebagai bahan alami untuk upaya preventif dan promotif kesehatan bagi masyarakat nusukan Banjarsari Surakarta. Abdimas Unwahas 2(1):5-8. http://dx.doi.org/10.31942/abd.v2i1.1786.

[AVMA] American Veterinary Medical Association. 2013. Guidelines for the Euthanasia of Animal: 2013 Edition. Schaumburg (US): AVMA.

Ayala A, Muñoz MF, Argüelles S. 2014. Lipid peroxidation: Production, metabolism, and signaling mechanisms of malondialdehyde and 4-hydroxy-2-nonenal. Oxid Med Cell Longev 2014:360438. http://dx.doi. org/10.1155/2014/360438.

Christijanti W, Utami NR, Iswara A. 2011. Efek pemberian antioksidan vitamin c dan e terhadap kualitas spermatozoa tikus putih terpapar allethrin. Biosaintifika: Journal of Biology \& Biology Education 2(1):18-26. https://doi.org/10.15294/biosaintifika. v2i1.1148.

Dianasari D, Fajrin A. 2015. Uji aktivitas antidiabetes ekstrak air kelopak bunga rosella (Hibiscus sabdariffa L.) pada tikus dengan metode induksi aloksan. Jurnal Farmasi Sains dan Terapan 2(1):1-4. https://doi.org/10.33508/jfst.v2i1.812. 
Hayati Z, Winda Y, Karmil TF, Azmy A. 2012. Anti-bacterial Activity of Roselle Flowers Extract (Hibiscus sabdariffa Linn) in Inhibiting Bacterial Growth Methicillinr Esistant Staphylococcus aureus. Proceedings of The 2nd Annual International Conference Syiah Kuala University 2012 \& The 8th IMT-GT Uninet Biosciences Conference (page 416-420), 22-24 November 2012, Banda Aceh (ID): Syiah Kuala University.

Hidayah N. 2011. Pengaruh Ketinggian Tempat Tumbuh Rosella dan Jenis Bahan Rosella terhadap Aktivitas Antioksidan Teh Kombucha Rosella [Undergraduate Thesis]. Malang: UIN Maulana Malik Ibrahim.

Fitria NL, Lyrawati D, Handaru M. 2015. Efek pemberian asam alfa lipoat terhadap kadar MDAdan gambaran histologi pada hati tikus wistar jantan dengan diabetes melitus tipe 1. Jurnal Kedokteran Brawijaya 28(3):170-176. https://doi.org/10.21776/ ub.jkb.2015.028.03.2.

Harun I, Susanto H, Rosidi A. 2017. Pemberian tempe menurunkan kadar malondialdehyde (MDA) dan meningkatkan aktivitas enzim superoxide dismutase (SOD) pada tikus dengan aktivitas fisik tinggi. J Gizi Pangan 12(3):211-216. doi: 10.25182/ jgp.2017.12.3.211-216.

Lieberman M, Peet A. 2018. MARKS' Basic Medical Biochemistry. 5th Edition. Philadelphia (US): Wolters Kluwer.

Lemmens KJA, Vrolijk MF, Bouwman FG, Van de Vijgh WJF, Bast A, Haenen GRMM. 2014. The minor structural difference between the antioxidants quercetin and 4'o-methylquercetin has a major impact on their selective thiol toxicity. Int $\mathrm{J}$ Mol Sci 15(5):7475-7484. https://doi.org/10.3390/ ijms 15057475 .

Mardiah SR, Rahayu A, Ashadi RW, Sawarni H 2009. Budi Daya dan Pengolahan Rosela: Si Merah Segudang Manfaat. Jakarta (ID): Agromedia.

Nurnasari E, Khuluq AD. 2017. Potensi diversifikasi rosela herbal (Hibiscus Sabdariffa L.) untuk pangan dan kesehatan. Buletin Tanaman Tembakau, Serat \& Minyak Industri 9(2):82-92.

Oktiarni D, Khasanah SN, Adfa M, Nesbah N, Angasa E. 2016. Pengaruh boraks, asam dan basa terhadap pergeseran panjang gelombang ekstrak air bunga rosella
(Hibiscus sabdariffa Linn.) Gradien: Jurnal Ilmiah MIPA 12(2):1187-1191.

Pramita R, Widodo CS, Juswono UP. 2014, Pengaruh ekstrak kelopak rosella (Hibiscus sabdariffa L.) pada aktivitas SOD dan MDA mata tikus (Rattus wistar) yang dipapar radiasi gamma. Natural B 2(4):375-379.

Priska M, Peni N, Carvallo L, Ngapa YD. 2018. Review: Antosianin dan pemanfaatannya. Cakra Kimia: Indonesian E-Journal of Applied Chemistry 6(2):79-97.

[MoH RI] Ministry of Health Republic of Indonesia. 2018. Hasil Utama Riskesdas. https://kesmas.kemkes.go.id/assets/ upload/dir_519d41d8cd98f00/files/Hasilriskesdas-2018 1274.pdf.pdf [Accessed 30th January 2020].

Riskiyani S, Jannah M, Rahman A. 2015. Aspek sosial budaya konsumsi minuman beralkohol (Tuak) di Kabupaten Toraja Utara. Media Kesehatan Masyarakat Indonesia 11(2):76-85. http://dx.doi. org/10.30597/mkmi.v11i2.520.

Sukardi S, MulyartoAR, Safera W. 2007. Optimasi waktu ekstraksi terhadap kandungan tanin pada bubuk ekstrak daun jambu biji (Psidii Folium) serta biaya produksinya. Jurnal Teknologi Pertanian 8(2):88-94.

Syafitri NE, Bintang M, Falah S. 2014. Kandungan fitokimia, total fenol, dan total flavonoid ekstrak buah harendong (Melastoma affine D. Don). Current Biochemistry 1(3):105-115. https://doi.org/10.29244/ cb.1.3.\%25p.

Tritama TK. 2015. Konsumsi alkohol dan pengaruhnya terhadap kesehatan. Medical Journal of Lampung University 4(8):7-10.

Ulilalbab A, Wirjatmadi B, Adriani M. 2015. Ekstrak kelopak rosella merah mencegah kenaikan malondialdehid tikus wistar yang dipapar asap rokok JIFI 13(2):215-220.

Werdhasari A. 2014. Peran antioksidan bagi kesehatan. Indonesian Jurnal Biotek Medisiana Indonesia 3(2):59-68.

Zakhari S. 2006. Overview: How is alcohol metabolized by the body? Alcohol Res Health 29(4):245-254.

Zuraida Z, Yerizel E, Anas E. 2015. Pengaruh pemberian ekstrak rosella (Hibiscus Sabdariffa Linn) terhadap kadar malondialdehid dan aktivitas katalase tikus yang terpapar karbon tetraklorida. Jurnal Kesehatan Andalas 4(3):795-802. https:// doi.org/10.25077/jka.v4i3.366. 